\title{
有機溶媒中におけるコロイド結晶と固定化
}

\section{Colloidal Crystallization in Organic Solvents and Immobilization}

吉 永 耕 二

1.はじめに

ある範囲内の大きさの粒子径をもち、かつ产の粒径が光 ろったコロイド粒子が水溶液や低級アルコール溶液中で結 晶構造のような粒子配列、いわゆる“ コロイド結晶”が形 成することは、以前から知られている。この粒子配列の原 理は極めて簡単なものであり、基本的にはコロイド粒子表 面電荷による粒子間静電的反発に基づくものである ${ }^{11}$ 。単 分散な球状コロイド粒子を含む閉鎖系溶液内で脱イオン化 を進めていくと粒子表面の電気二重層が拡がっていき、こ の電気二重層を含んだ粒子径がこの閉鎖系の容積よりも大 きくなったときに、粒子のブラウン運動は粒子間静電反発 によって極めて制限され、粒子が最密充填されて配列する 現象である。したがって、大きな粒子径または高比重の粒 子は地上では重力による沈降力が、また小さな粒子径また は小比重の粒子はブラウン運動が粒子間静電反発力より大 きくなるために、結晶構造を形成しない。コロイダルシリ カの場合、粒子径 100 200nm の粒子が水溶液中でコロイ ド結晶を形成し、オパール樣の虹彩構造色を発する。この コロイド結晶化に関しては、これまでにコロイダルシリカ やポリスチレンラテックスなどを用いて、多くの研究が行 われているが、この結晶化が分散溶液中のみで観測される 現象であるため、これまで材料という観点からの関心は払 われていなかった。しかし、最近になってこのコロイド結 晶構造のフォトニック結晶2)への応用がにわかに注目を集 めてきており、光学素子としての微粒子配列体の調製に関 心が深まっている。著者らのグループは、以前より微粒子 の三次元配列と言う観点から、有機溶媒中でのコロイド結 晶形成と产の固定化について研究を進めてきた。本稿では ポリマーをグラフトしたシリカの有機溶媒中でのコロイド 結晶化とラジカル重合によるこの結晶のゲル中への固定化 について述べる。

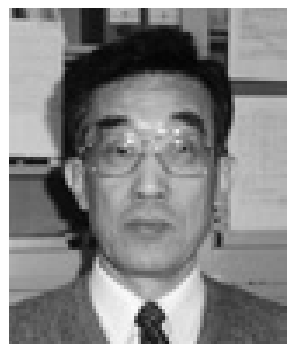

KOHJI YOSHINAGA

九州工業大学工学部 教授 工学博士 干 804-8550 北九州市戶畑区仙水町 Tel : 093-884-3316 Fax :093-884-3316 E-mail : khyosina@che.kyutech.ac.jp 〈専門〉高分子化学、複合材料 〈趣味〉テニス
2.コロイダルシリカへのポリマーグラフト ${ }^{3)}$

無機化合物に有機物を結合させて、弚の表面へ疎水性や 官能基を付与するとき、いろいろな方法が用いられている が、もっとも簡便な方法のひとつにシランカップリング剂 との反応を利用する方法がある。この方法は、粒子間の凝 集を防ぐような反応条件を設定することができれば、コロ イド粒子表面へのポリマーグラフトにも有効である。この 反応で用いるポリマーシランカップリング剂は、比較的簡 便な方法によって合成することができる。このシランカッ プリング斉とコロイダルシリカの反応は、ポリマーが溶解 し、かつシリカ粒子の凝集を招かないような高極性有機溶 媒中での加熱還流によって行うことができる。例えば、単 分散コロイダルシリカ(粒子径 136nm)を 15wt％分散させ たエタノール溶液 $6 \mathrm{~cm}^{3}$ に 1,2-ジメトキシエタンまたはア セトン $50 \mathrm{~cm}^{3}$ 及びトリメトキシシリル基をもつポリ(無水 マレイン酸-スチレン)(分子量 4600)0.5g を加えて、還流 下で 3 時間加熱すると、このポリマーを $74 \mathrm{mg} / \mathrm{g}$ 結合した ポリ(無水マレイン酸-スチレン)/シリカ(P(MA-ST)/ $\left.\mathrm{SiO}_{2}\right)$ を単分散の状態で得ることができた。この方法の欠 点は、ポリマーの分子量が大きくなるとグラフト量が小さ くなることである。この欠点を補う方法として、最近になっ て原子移動ラジカル重合法 ${ }^{4}$ が注目されている。この重合 法では、表面からリビング的にラジカル重合が進行するの で、ポリマー鎖の分子量やグラフト量が任意に制御できる ことが特徵である。

\section{3 . 有機溶媒中でのコロイド結晶形成}

ポリマーをグラフトしたシリカを有機溶媒中へ分散させ て、コロイド結晶化を調べたところ、高極性で、しかもグ ラフトポリマーに対して良溶媒中で結晶化することが明ら かになった5)。図 1 に有機溶媒中での代表的なポリマーグ ラフトシリカのコロイド結晶を示した。また、表 1 にいろ いろな有機溶媒中でのポリマー修飾シリカのコロイド結晶 化における臨界体積分率 $\left(\phi_{0}\right)$ 、すなわち結晶化に必要な 最小体積分率、を示した。一般には、この $\phi_{0}$ が低い粒子 分散系が安定なコロイド結晶を形成していることになる。 ポリ(メタクリル酸メチル)/シリカ $\left(\mathrm{PMMA} / \mathrm{SiO}_{2}\right)$ はアセ トニトリル、アセトン、アクリロニトリル中で結晶化した が、おもしろいことにポリスチレン/シリカ $\left(\mathrm{PST} / \mathrm{SiO}_{2}\right)$ は ニトロベンゼン中のみで結晶化が観測された。また、この 


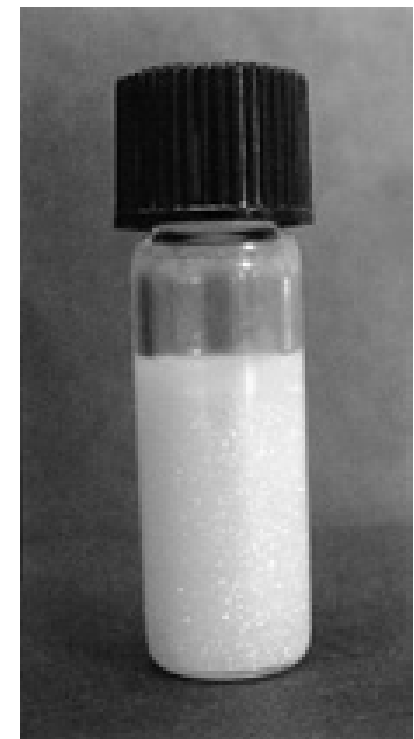

图 1 ニトロベンゼン中での PST $/ \mathrm{SiO}_{2}$ のコロイド結晶。

表 1 有機溶媒中でのポリマーグラフトシリカのコロイド 結晶化における臨界体積分率 $\left(\phi_{o}\right)^{\text {a) }}$

\begin{tabular}{ccccc}
\hline \multirow{2}{*}{ 溶 媒 } & \multicolumn{5}{c}{$\phi_{0}$} \\
\cline { 2 - 5 } & $\mathrm{SiO}_{2}$ (未修飾) $\mathrm{P}(\mathrm{MA}-\mathrm{ST}) / \mathrm{SiO}_{2}$ & $\mathrm{PST} / \mathrm{SiO}_{2}$ & $\mathrm{PMMA} / \mathrm{SiO}_{2}$ \\
\hline アセトニトルル & 0.0208 & 0.0130 & - & 0.0230 \\
\hline ニトロベンゼ & - & 0.0501 & 0,0720 & - \\
\hline エタノール & 0.0730 & - & - & - \\
\hline アセトン & 0.0245 & 0.0260 & - & 0.0530 \\
\hline クロロホルム & - & -1 & - & - \\
\hline アクリロニトル & - & 0.0450 & - & 0.0550 \\
\hline
\end{tabular}

a)—”は結晶化しない系を示す。

コロイド結晶が形成するためには、グラフトポリマーと溶 媒のマッチングが存在することが認められたが、关の理由 は明らかでない。この有機溶媒中におけるポリマーグラフ トシリカのコロイド結晶化での $\phi_{0}$ は 0.02 0.08 となり、 水溶液系における未修飾シリカの关れよりも百倍以上高く なった。これは、有機溶媒が水よりも誘電率が低いこと ${ }^{11}$ 及びポリマーグラフトのために表面荷電に寄与するシリカ 上のヒドロキシル基数が減少したことによって、静電的反 発力が低下したことに起因すると推測される。アセトニト リル中 $\mathrm{P}(\mathrm{MA}-\mathrm{ST}) / \mathrm{SiO}_{2}$ の分散溶液へ $\mathrm{NH}_{4} \mathrm{PF}_{6}$ を添加する と、コロイド結晶化に対する $\phi_{0}$ (は著しく増大し、ある添 加量以上では結晶化は認められなくなった。このことは、

有機溶媒系でのポリマーグラフトシリカのコロイド結晶化 は、水溶液中の光れと同樣に粒子間の静電的反発に起因し ていることを支持するものである。また、アセトニトリル 中での $\mathrm{P}(\mathrm{MA}-\mathrm{ST}) / \mathrm{SiO}_{2}$ のコロイド結晶化における $\phi_{0}$ へ のポリマーグラフト量の影響について調べたところ、20 $\mathrm{mg} / \mathrm{g}$ 程度以上においてグラフト量は $\phi_{o}$ にほとんど影響 しないこともわかった。しかし、グラフトポリマー分子量 の吅への影響については、PST $/ \mathrm{SiO}_{2}$ では、分子量ととも に $\phi_{0}$ は低下し、また $\mathrm{PMMA} / \mathrm{SiO}_{2}$ では分子量とともにわ ずかに増大する傾向がみられた。このことは、有機溶媒中

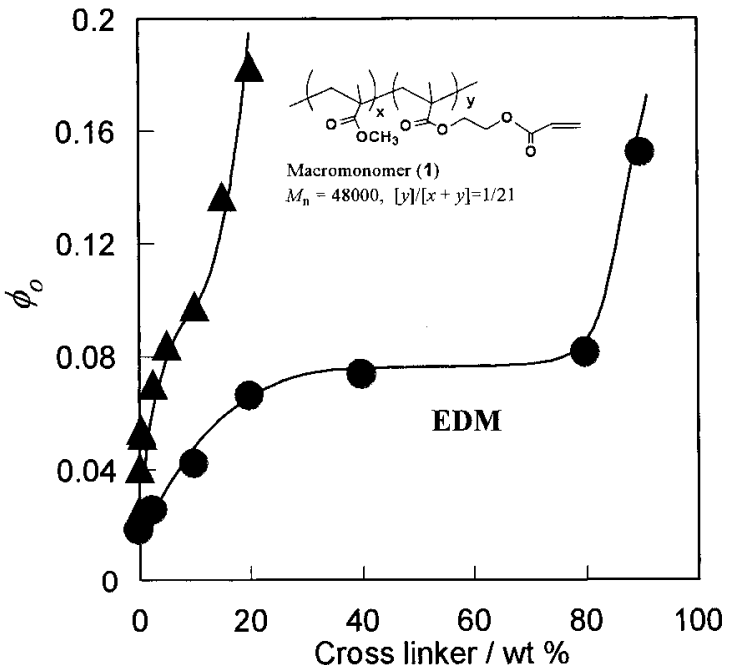

図 2 有アセトニトリル中での $\mathrm{PMMA} / \mathrm{SiO}_{2}$ のコロイド 結晶化における臨界体積分率 $\left(\phi_{0}\right)$ に及ぼす架橋剂 添加の効果。

でのポリマーグラフトシリカのコロイド結晶化では、表面 ポリマーが光の過程において重要な役割を演じていること を示唆すものである。しかしながら、コロイド結晶化に直 接関連すると考えられる表面電荷とポリマーグラフト量お よびポリマーの一次構造との関係については不明な点が多 い。

\section{4. ラジカル重合によるゲル化固定}

コロイド結晶の固定化は、これまでにコロイダルシリカ を用いて、ポリアクリル酸やポリアクリルアミドのヒドロ ゲル化によって行われた研究例はあるあ。 。しかし、この固 定化によって得られた粒子配列ゲルの機能材料への応用は、 ヒドロゲルを固化かフィルム状にすることが困難であるの で、不可能に近い。一方、ポリマーグラフトしたシリカは 有機媒体中でコロイド結晶化が起こるので、有機化合物を 用いてのゲル化や重合反応によって固体化が可能である。 これに関しては、 $\mathrm{PMMA} / \mathrm{SiO}_{2}$ がアクリロニトリルなどの 重合性ビニルモノマー中でコロイド結晶化するので、光の 結晶が形成した分散溶液への紫外線照射によるラジカル重 合による固定化がもっとも簡単な方法と思われるが、実際 には重合時の体積収縮と相分離のために、生成した重合物 中にコロイド結晶構造を保持したままの固定化は不可能で あった。乥こで、コロイド結晶を形成している分散溶液へ 重合性モノマーと架橋ビニル化合物を添加して、光のラジ カル共重合によって得られるオルガノゲル中への固定化を 試みだ)。このゲル化では、架橋㓢にポリ(メタクリル酸 メチル-2-ヒドロキシエチルメタクリル酸)にメタクリロイ ル基を導入したマクロモノマー(1)および1,2-ジメタクリ ロイルエタン(EDM)を用いた。前者は、ラジカル重合に ともなうコロイド結晶構造のひずみを抑制するためにでき るだけ架橋点を少なくしょうとする意図から用いられたも のである。まず、ラジカル重合によるゲル化の最適条件を 探索するために、アセトニトリル中での $\mathrm{PMMA} / \mathrm{SiO}_{2}$ の 
コロイド結晶化に及ぼすメタクリル酸メチル及び架橋剂の 添加効果を調べたところ、これらの添加はコロイド結晶化 における $\phi_{0}$ を増大させることが明らかになった(図 2)。 とくに、マクロモノマー1の添加によって著しく $\phi_{o}$ が増 大する、すなわち結晶の不安定化することが観測された。 これらの結果に基づいて、アセトニトリル中のPMMA/ $\mathrm{SiO}_{2}$ の体積分率 $(\phi)$ を $\phi=0.08 \sim 0.152 、 \mathrm{MMA}$ 濃度を 2.02〜2.31 mol L-1、架橋剂濃度を 4.2〜 7.1wt\%、2,2’ - アゾ ビス(イソブチロニトリル)量を $0.051 \sim 0.100 \mathrm{~mol} \mathrm{~L}^{-1}$ にして 10x $10 \mathrm{~mm}$ 石英セルを用いて、 $25^{\circ} \mathrm{C}$ にて高圧水銀ランプ (500W)を3時間照射して重合を行った。光の結果、マク ロモノマー1を用いた系では、ポリマーゲルの生成は観 測されたが、コロイド結晶は消失した。一方、EDM を架 橋剂に用いた系では、ゲル表面及び内部にBragg 反射に 基づく虹彩色の輝きが観察され、コロイド結晶構造が保た れていることがわかった。谷のゲルの反射スペクトルのひ とつを図 3 に示す。この図から、反射ピークの強度はゲル 化前に比べて著しく低く、また広くなっており、単位面積 あたりの結晶数が減少及びひずみが生じていることがわか る。これは、ラジカル重合におけるゲル化の不均一性に基 づくものであると推測される。

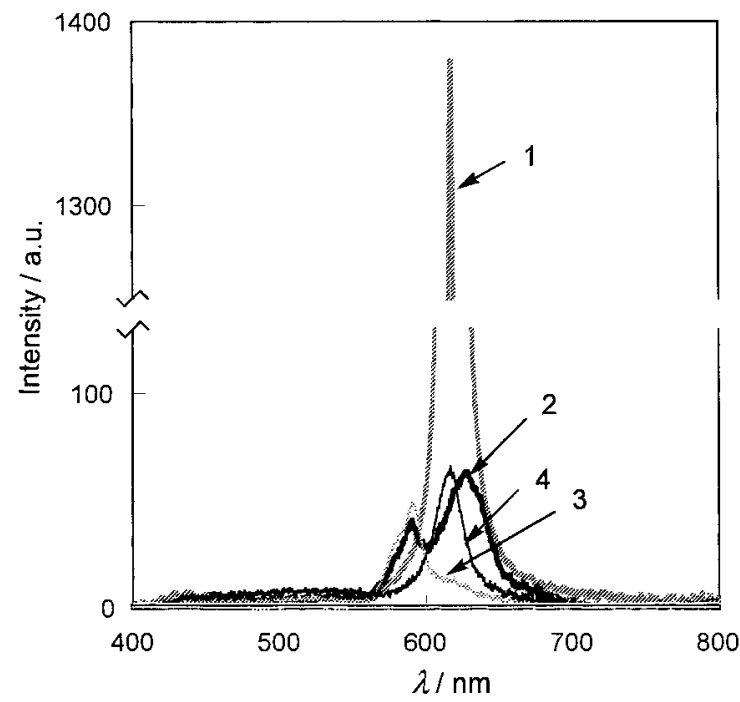

図 3 アセトニトリル中での $\mathrm{PMMA} / \mathrm{SiO}_{2}$ のコロイド結 晶(1)、および $10 \mathrm{~mm}$ セル中メタクリル酸メチルと EDM の共重合によって得られたゲルの前面(2)， 断面(3)、後面(4)の反射スペクトル。

そこで、2mm セルを用いて、同樣な方法によってゲル 化を行ったところ、虹彩色の輝くポリマーゲルを得ること ができた。光のゲルの写真及び反射スペクトルを光れ攵れ 図 4及び図 5 に示す。反射ピークは、10mm セルを用いた ときよりも強度が大きくなり、またゲル化前の光れに比べ てピーク波長も移動していないことがわかる。この場合、 $\mathrm{PMMA} / \mathrm{SiO}_{2}$ の体積分率、架橋斉濃度およびラジカル開始 剂濃度が低くなるほど、反射ピークが高く、シャープになっ た。このことは、コロイド結晶構造の保持がラジカル重合 においてゲル化速度が遅く、かつ架橋度を少なくすること によって達成されることを示している。ゲル化 PMMA/

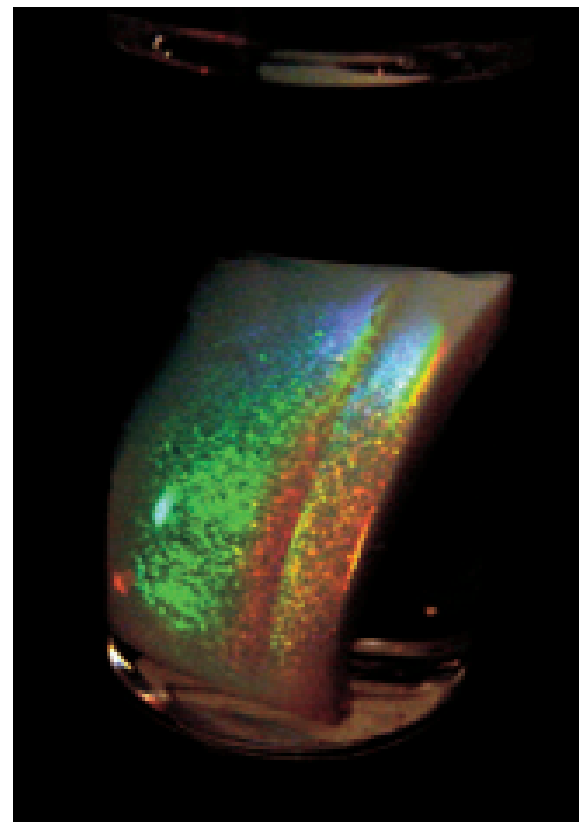

図 $4 \mathrm{PMMA} / \mathrm{SiO}_{2}$ のコロイド結晶を包含したポリ(メタ クリル酸メチル)ゲル。

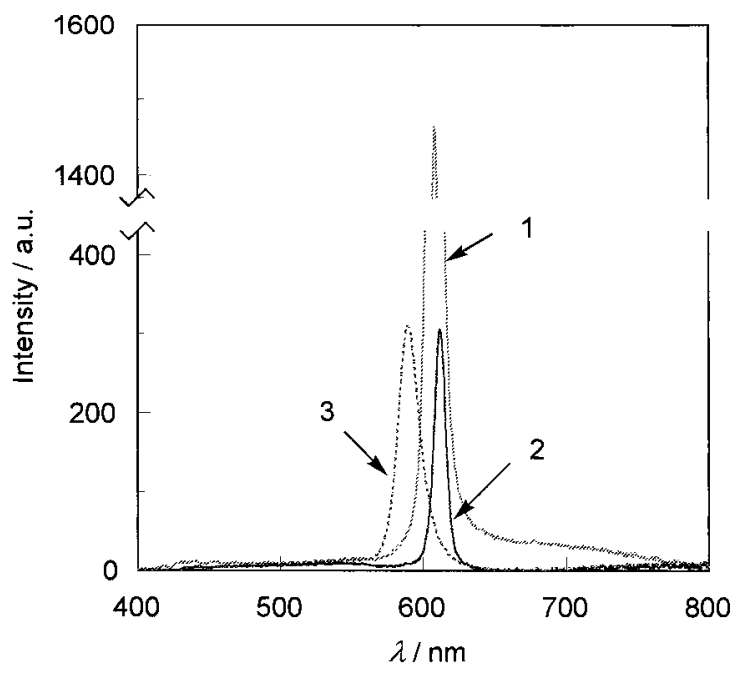

図 5 アセトニトリル中での $\mathrm{PMMA} / \mathrm{SiO}_{2}$ のコロイド結 晶(1)、および $2 \mathrm{~mm}$ セル中メタクリル酸メチルと EDM の共重合によって得られたゲルの前面(2)、 後面(3)の反射スペクトル。

$\mathrm{SiO}_{2}(\phi=0.090)$ 結晶の反射スペクトルピークから算出した 粒子間距離は、ゲル化前では $274 \mathrm{~nm}$ であったものが、セ ルの前面では $274 \mathrm{~nm}$ 、後面では $273 \mathrm{~nm}$ となり、結晶はゲ ル化によってほとんど歪んでいないことも判明した。また、 平均結晶サイズを反射ピークの半値幅より計算した結果、 ゲル化前では $15.2 \mu \mathrm{m}$ であったものが、ゲル化後のセル前 面と後面で光れ光れ $11.0 \mu \mathrm{m}$ および $3.8 \mu \mathrm{m}$ となり、ゲル化 に伴って結晶サイズが小さくなっていることが観測された。 同樣の方法によって、ポリ (N,N-ジメチルアクリルアミド) ゲル中への固定も可能であることもわかった。さらに、1 $\mathrm{mm}$ セルを用いて同樣にコロイド結晶のゲル化固定を試み たが、コロイド結晶構造を保持した状態でのゲルは得られ なかった。これは $1 \mathrm{~mm}$ セルの小さい容積がラジカル重合 における体積収縮を補償できなくなり、ひずみが大きく なったためと考えられる。 


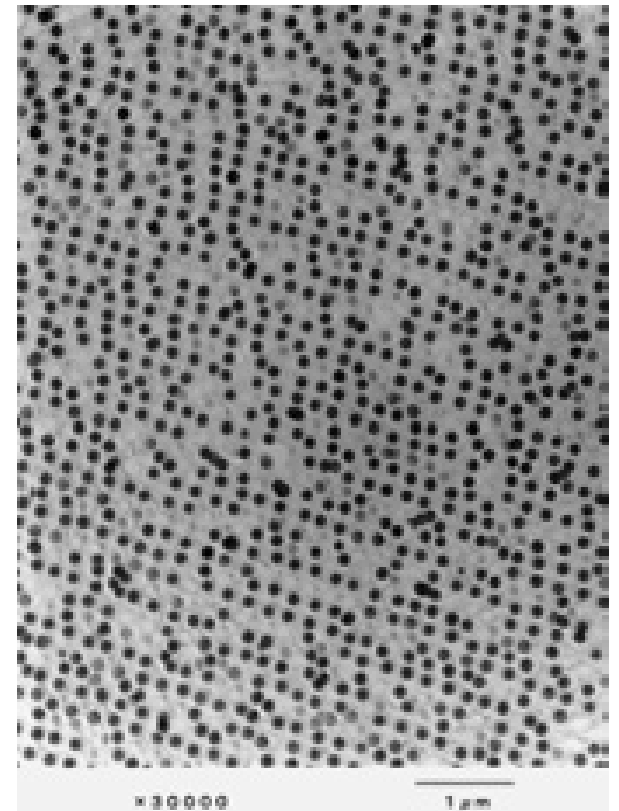

図 $6 \mathrm{PMMA} / \mathrm{SiO}_{2}$ のコロイド結晶を包含したポリ(メタ クリル酸メチル)ゲルの乾燥後の透過顕微鏡写真。

図 6 に、PMMA/SiO 2 のコロイド結晶を固定したゲルを 乾燥して得られた乾燥ゲルの透過電子顕微鏡写真を示す。 この図から、ゲル中では粒子はお互いに独立して存在し、 しかも部分的には粒子配列が観測された。このことは、コ ロイド結晶のゲル化において、架橋ポリマー鎖はコロイド 単結晶を包み込んでいるのではなく、結晶内粒子間を貫通 してネットワークを形成していることを示すものである。

\section{5.おわりに}

ポリマーをグラフトしたコロイダルシリカの有機溶媒中 でのコロイド結晶の形成及びゲル化による炎の固定化につ いて述べた。コロイド結晶固定化は、微粒子のポリマーマ トリックス中への三次元配列という観点からみると極めて 魅力的であり、いろいろな材料作製への応用の可能性を有
している。しかし、このコロイド結晶固定化ゲルを機能材 料への応用するためには、結晶構造を破壊せずに何らかの 方法でゲルを固化する必要があり、また多樣な材料への応 用を考える場合、シリカよりも高い誘電率や屈折率の粒子 のコロイド結晶固定化が必要となるなどの課題も多い。最 近、シリカ以外の微粒子のコロイド結晶化 ${ }^{8)}$ 及び結晶サイ ズの向上 ${ }^{9}$ を目指しての研究もみられ、このコロイド結晶 固定化の今後の展開が期待される。

\section{参考文献}

1) T. Okubo, Acc. Chem. Res. 21, 281(1988) ; T. Okubo, Prog. Polym. Sci., 18, 481(1993) .

2) W. H. Zubrzycki, H. Hou, A. Alleman, Nature, 407, 983 (2000) ; A. Chutinan, S. Noda, Phys. Rev. B, 62, 4488 (2000) .

3) K. Yoshinaga, K. Nakanishi, Composite Interfaces, 2, 95 (1994) ; K. Yoshinaga, Y. Tani, Y. Tanaka, Colloid Polym. Sci., 280, 85(2002) .

4) T. K. Mandal, M. S. Fleming, D. R. Walt, Chem. Mater., 12, 3481(2000) ; C. Perruchot, M. A. Khan, A. Kamitsi, S. P. Armes, Langmuir, 17, 4479(2001) .

5) K. Yoshinaga, M. Chiyoda, H. Nishida, M. Komatsu, Colloid Polym. Sci., 277, 479(1999) ; K. Yoshinaga, M. Chiyoda, H. Ishiki, T. Okubo, Colloids Surf. A, 204, 285 (2002) .

6) Y. Iwayama, J. Nakayama, Y. Taniguchi, M. Takasaka, K. Ito, T. Shinohara, T. Sawada, M. Yonese, Langmuir, 19, 977(2003) .

7) K. Yoshinaga, K. Fujiwara, Y. Tanaka, M. Nakanishi, M. Takesue, Chem. Lett., 32, 1082(2003) .

8) M. A. A-Daous, A. Stein, Chem. Mater., 15, 2638(2003) .

9) 山中、林、村井、米勢、伊藤、澤田、第 56 回コロイ ド及び界面化学討論会講演要旨集、73(2003). 